\title{
Die verhouding fussen onderrig en navorsing in universitêre verband
}

\author{
H.W. Rossouw \\ Departement Filosofie \\ Randse Afrikaanse Universiteit \\ JOHANNESBURG \\ E-pos: rossouwh@iafrica.com \\ Abstract \\ The relationship between teaching and research in the university \\ The relationship between teaching and research is one aspect of the \\ current dilemma concerning universities that has increasingly become the \\ topic of debate. Among the uncertainties involved in the situation of the \\ university belongs an apparent tension between the teaching and research \\ tasks of this institution. The question is whether this tension points to an \\ intrinsic incompatibility of activities that do not really belong together and \\ which consequently cause mutual disruption or whether it is it only a matter \\ of an imbalance between interdependent functions. And if the latter, how \\ can a healthy balance between university teaching and research be \\ theoretically accounted for and practically implemented? The article \\ discusses these questions, and, using the concept of "the academic \\ learning process", argues in favour of the unity between teaching and \\ research in the context of the university.
}

\section{Historiese en konseptuele gesigspunte}

Daar bestaan ' $n$ opvatting dat navorsing eers sedert ongeveer die begin van die 19de eeu ' $n$ uitdruklike taak op die agenda van die universiteit geword het, en dat dit daarna baie lank geneem het voordat die tradisionele begunstiging van onderrig plek gemaak het vir 'n gelyker behandeling van die twee funksies. Hoe 'n mens oor hierdie opvatting oordeel, hang af van jou konsepsie van navorsing.

Een moontlikheid is dat onder navorsing uitsluitlik verstaan word empiries-eksperimentele ondersoek wat op 'n georganiseerde en planmatige basis gedoen word om feitelike getuienis in te win ter ondersteuning of weerlegging van verklarende of beskrywende teorieë. So geïnterpreteer, kan 'n mens wel sê dat navorsing eers in die loop van 
die 19de eeu 'n universitêre onderdak gevind het. Dat daar teen hierdie vorm van navorsing lank 'n sekere weerstand aan universiteite bestaan het, miskien met uitsondering van sommige Duitse universiteite, is eweneens waar. Daar moet egter onmiddellik bygevoeg word dat so 'n begrip van navorsing baie eng, en daarom beperkend is, om nie te sê misleidend nie.

Ek sou graag wil uitgaan van 'n breër begrip van navorsing. Dit is naamlik 'n begrip wat naas empiriese en eksperimentele ondersoek ook daardie soort intellektuele funksies insluit wat te make het met die herevaluering, herinterpretasie en integrasie van oorgelewerde kennis. Dit is naamlik die intellektuele funksies wat in die Middeleeue met die term studium aangedui is en in die Britse universitêre tradisie scholarship genoem word. Dat 'n mens laasgenoemde ook tot navorsing sal reken, hang daarmee saam dat dit dikwels deur sulke denkoperasies is dat nuwe insigte verwerf word wat bydra tot die begripsmatige verheldering van die mens se ervaringsbewussyn of tot die uitbreiding van die mens se kennishorison.

Dit is veral in die humaniora of hermeneutiese dissiplines dat hierdie intellektuele funksies 'n sentrale rol speel. Hierdie rol kom neer op die herhalende heropname en oorskryding van bestaande insigte wat gewoonlik lei tot wat 'n mens 'n spiraalvormige progressie in die betrokke kennisproses kan noem. Hierdie soort progressie, wat eie is aan die humaniora, kom egter ook voor in die teoretiese komponent van alle empiriese navorsing. Vir 'n meer omvattende opvatting van navorsing hoef 'n mens daarom nie slegs na die humaniora te kyk nie. In elk geval sluit die konsepsie van navorsing wat ek wil voorstel alle bedrywighede van die akademiese denke in waardeur die intellektuele insig in die menslike envaring sistematies en metodies vernuwe word. So 'n vernuwing van intellektuele insig kan plaasvind langs die weg van verdieping, verfyning, verbreding, hersiening of vermeerdering. Die belangrike is dat hierdie bedrywighede van die akademiese denke ook kritiese studie, refleksie en interpretasie insluit. 1

$1 \quad$ Elton (1986) wat ook die vraag aan die orde stel of die verhouding tussen navorsing en onderrig een van simbiose of een van konflik is, onderskei tussen scholarship en navorsing en beperk laasgenoemde soort akademiese ondememing dan tot empiriesekspenmentele ondersoek. Volgens hom is scholarship noodsaaklik vir sowel goeie onderrig as goeie navorsing

Niks verhoed 'n mens om op hierdie wyse skerp terminologiese onderskeidings te maak nie. By gebrek van 'n toereikende ekwivalent vir scholarship in Afrikaans, en ook vanweë die feit dat die woord scholarship dikwels as sinoniem vir 'n breë begrip van navorsing gebruik word, verkies ek om by die twee terme onderrig en navorsing te hou, mits "navorsing" dan in 'n omvattende sin verstaan word. Vgl. Boyer (1990) 
H.W. Rossouw

So gesien, was daar reeds sedert die ontstaan van die universiteit in die Middeleeue sprake van bepaalde vorme van navorsing wat naas en in samehang met onderrig beoefen is. Hierdie vorme van navorsing het weliswaar nog nie neergekom op 'n georganiseerde en doelgerigte uitskuif van die kennisfronte deur goed beplande eksperimentele programme en die inspan van gespesialiseerde toerusting en tegniese kundigheid nie. Die soeke na nuwe kennis was meestal 'n kwessie van scholarship, van 'n persoonlike verbintenis tot geleerdheid-deur-studium van 'n individuele akademikus wat 'n spesiale belangstelling vir een of ander onderwerp binne die betrokke dissiplinêre tradisie ontwikkel het. Wat aan die begin van die 19 de eeu gebeur het, was die geleidelike aanvaarding van die moderne natuurwetenskappe, met hulle empirieseksperimentele navorsingsmetodieke en navorsingsmodel, as volwaardige universitêre dissiplines. Dit is hierdie vernuwing in die akademiese aanbod en in die navorsingskultuur van die tradisionele universiteit wat een van die belangrikste faktore was in die oorgang na wat 'n mens die moderne universiteit kan noem.

Een van die opmerklike ontwikkelinge in die moderne universiteit was juis die toenemende verselfstandiging van die navorsingsfunksie teenoor die onderrigfunksie. 'n Mens kan hierdie verselfstandiging onder meer toeskryf aan die feit dat empiriese en eksperimentele navorsing 'n logistieke sofistikasie nodig het - in die vorm van toerusting, geriewe en vaardighede - wat nie opsigtelik verband hou met of in die verlengde lê van die vereistes en voorvereistes van die onderrigsituasie nie. Dit het daarom ook die geneigdheid om in 'n organisatoriese opsig as 't ware aparte strukture te presipiteer, soos institute, buro's of sentra, náa die leerstoele of departemente waarin onderrigaktiwiteite gewoonlik georganiseer word. So het hierdie vorm van navorsing 'n eie institusionele identiteit en infrastruktuur ontwikkel wat dit moontlik gemaak het om 'n oënskynlik selfstandige bestaan buite die verhouding tot universitêre onderrig om te ontwikkel. In hierdie vorm het navorsing ook, anders as die studium of scholarship van die Middeleeuse en vroegmoderne universiteit, toenemend in kompetisie met die akademiese onderrigfunksie begin tree. Navorsing en onderrig het met mekaar begin wedywer om die toesegging van skaars hulpbronne - mense, tyd en fondse. Maar die mededinging het ook al hoe meer gegaan om die vraag watter van hierdie twee universitêre prestasiegebiede vir die meeste akademiese status en prestige kan sorg.

wat in sy heroorweging van die begrip scholarship vier kategorieë van scholarship onderskei, te wete die van "discovery", "application", "teaching" en "integration". Vgl. ook Paulsen en Feldman (1995) oor die rekonseptualisering van scholarship. 
Dit is veral sedert die Tweede Wêreldoorlog dat akademiese navorsing in bepaalde soorte wetenskappe 'n al hoe sterker posisie teenoor akademiese onderrig begin verwerf het. Hierdie ontwikkeling hang nou saam met die deurslaggewende rol wat tegnologies gerigte empiriese navorsing in die oorlogspoging gespeel het, en daarna ook in die industriële omwentelinge van die na-oorlogse jare. Veral die mate waarin bedryfsgeleide navorsing en ontwikkeling die dryfkrag agter ekonomiese groei en vooruitgang geword het, het daaraan ' $n$ toenemende belang verleen; ' $n$ belang wat ook erkenning gekry het in die finansiële en morele ondersteuning wat dit geniet. Groot bedrae geld het uit sowel die staatskas as private bronne vir navorsing beskikbaar geword, terwyl die openbare prestige-waarde daarvan toenemend gestyg het.

\section{Aansprake ten gunste van die onderigfunksie}

Mettertyd het daar by baie akademici wat nie so regstreeks by navorsing van hierdie aard betrokke is nie, die perspesie begin posvat dat navorsing onderrig geleidelik aan die verdring is - indien nie op die verpligte daaglikse agenda van die universiteit nie, dan tog in missiebepalings en in die beleids- en befondsingsprioriteite van sentrale en institusionele owerhede. Navorsing het daarby oënskynlik al hoe meer die voorkeur begin kry wanneer dit gaan om loopbaanpromosies of eerbewyse ter erkenning van prestasie. In die algemeen kom dit voor asof akademiese status en aansien bepaal word aan die hand van navorsingsuitsette eerder as onderrigbetrokkenheid en onderrigsukses. ${ }^{2}$

Dit is opvallend dat die onderrigfunksie van die universiteit die laaste tyd toenemend en met 'n sekere driftigheid sy aansprake op erkenning opnuut laat geld. Dit geskied gedeeltelik onder aandrang van verbruiksgeoriënteerde studente wat in die lesinglokaal waarde vir geld soek, maar veral ook vanweë nuwe besinning oor die konstituerende funksies van die universiteit ( $\mathrm{vgl}$. Toch, 1990). Daar is 'n groeiende besorgdheid oor wat as die verwaarlosing van onderrig beleef en getipeer word. Mense protesteer daarteen dat te veel van die tyd en intellektuele energie van akademici wat verantwoordelik is vir die vervulling van universiteitstake, weggelei word van die onderrigfunksie. Daar word geywer vir die rehabilitasie van onderrig as 'n sentrale onderneming van

2 Vergelyk die uitspraak in die bekende dokument van die OECD (Organisation for Economic Co-operation and Development) Universities under Scrutiny (1987:54): "Of all the functions of universities it is their role in research that today receives the greatest emphasis by govemments and by academics within allmost all OECD countries ... In most, the volume and quality of university's research effort is now the best guide to its standing and prestige." 
die universiteit wat net soos navorsing spesiale aanmoediging en daadwerklike bevordering verdien. ' $n$ Teken hiervan is - sedert 'n dekade of drie gelede - onder meer die totstandkoming van buro's vir universiteitsonderwys wat deskundige aandag gee aan die verbetering van onderrigvermoëns en die bevordering van byderwetse onderrigstrategieë en -metodieke. ' $n$ Ander teken is die meer resente instelling van pryse en toekennings vir die erkenning en beloning van goeie onderrig; skemas met die doel om die gevoel by toegewyde dosente teen te werk dat sulke onderrig nie (of nie meer) tel nie.

In die literatuur oor die universiteitswese tree daar eweneens skrywers na vore wat hulle sterk vir die herwaardering van die universiteit se onderrigfunksie bemoei. Atkinson en Tuzin (1992) pleit byvoorbeeld vir 'n opgradering van die onderrigmissie en die onderrigeffektiwiteit aan Amerikaanse "research" universiteite om sodoende die balans tussen onderrig en navorsing te herstel. Hierdie balans is volgens hulle tot so 'n mate deur 'n oorwaardering van die navorsingsfunksie versteur dat daar sprake is van ' $n$ waardekrisis in die universiteitskultuur van hierdie inrigtings.

Ander skrywers trek sterk te velde teen die publish or perish-sindroom en die eensydige druk wat dit op akademici plaas. lemand soos Jacques Barzun, ' $n$ voormalige president van die Universiteit van Chicago, is van mening dat hierdie sindroom "a superstitious regard for 'doing research" in die hand werk wat maklik kan lei tot 'n stortvloed publikasies wat deur niemand gelees word nie, maar wat desondanks beskou word as 'n teken van akademiese sukses, of as die kernvoorwaarde vir die ontwikkeling van ' $n$ akademiese loopbaan (Barzun, 1991:176). Aan die ander kant het die publish or perish-sindroom volgens Baker (1986:51) 'n "global trend of diminished commitment to teaching" tot gevolg gehad waarvan gevrees word dat dit op die lang duur 'n ernstige nadelige uitwerking op die gehalte van hoër onderwys kan hê. ${ }^{3}$

Daar is sommige pleitbesorgers van universiteitsonderrig wat nie net teen die groeiende hegemonie van navorsing ten koste van onderrig waarsku nie, maar selfs geneig is om na die ander uiterste te gaan en navorsing as 'n soort toevallige en onwesenlike aanhangsel van die as navorsing. maar beklemtoon dat die enigste soort navorsing wat tuis is aan die universiteit navorsing is wat versoenbaar is met onderrig, "the kind of research that is inseparable from classroom and seminar" (Nisbet, 1971:178). Hy spreek hom sterk uit teen die konsepsie van die universiteit as "one vast research instifute, with all else made subsidiary or superfluous, and with this vast research institute serving as the highest level of the national research establishment" (Nisbet, 1971:172). 
universiteit se kernbedrywighede te beskou. Hulle val gewoonlik terug op die beskouinge van kardinaal Newman in sy bekende boek oor The Idea of the University (1910 [1852]), wat sedert die middel van die 19de eeu ' $n$ groot invloed op veral die Britse denke oor die universiteitswese uitgeoefen het. Newman het betoog dat die universiteit primêr ' $n$ pedagogiese instituut is waar jong mense deur liberale of algemeen vormende onderwys opgevoed moet word vir die intellektuele en kulturele leierskap van die samelewing. Die uitbreiding van die bestaande korpus van kennis het hy nie tot die werksterrein van die universiteit gereken nie. Om die verwerwing van nuwe kennis te bevorder was volgens Newman die funksie van nie-universitêre akademies, institute en wetenskaplike verenigings soos die Royal Society.

Diegene wat Newman se beklemtoning van die onderrigfunksie van die universiteit laat herleef, staan weliswaar nie sonder meer afwysend teenoor die aanwesigheid van sekere navorsingsaktiwiteite aan die universiteit nie. Hulle regverdig hierdie aanwesigheid egter alleen op suiwer dienstigheidsgronde. Hulle argumenteer dat die universiteit, vanuit 'n prinsipiële gesigspunt gesien, navorsingsaktiwiteite goedskiks sou kan ontbeer, sonder om sy eie aard of soortlike identiteit daarmee prys te gee. Daar is met ander woorde volgens hierdie beskouing niks in die konsep van die universiteit wat die belang of die noodsaaklikheid van navorsing impliseer nie. Maar ook wat die praktyk betref, word die noodsaak ontken van 'n sinergistiese verhouding tussen onderrig en ondersoek binne die universitêre opset. Universitêre onderrig steun weliswaar op die resultate van navorsing wat een of ander tyd êrens verrig is, so word geargumenteer, maar universitêre onderrig as sodanig kan gedy onafhanklik daarvan of dit in institusionele verband naas universitêre ondersoek beoefen word al dan nie. 4

Barnett (1992) ontwikkel so 'n argument, maar dan met verwysing na die konsep van hoèr onderwys wat hy onderskei van die universiteit as 'n instelling van hoër onderwys. Navorsing, sê hy, is nie deel van wat ons onder hoür onderwys verstaan nie, selfs al sou daar ook vanuit 'n pragmatiese gesigspunt 'n saak uitgemaak kan word dat hoër onderwys nie sonder een of ander navorsingsbasis aangebied kan word nie en dat universiteite ook een of ander vorm van navorsing behoort te bedryf. "Knowledge in the context of discovery and knowledge in the context of transmission are entirely different enterprises" (Bamett, 1992:623). Dit is wel moontlik dat hierdie twee verskillende ondememings soms in die praktyk naas mekaar beoefen kan word. "The key point remains, however, research is seldom driven by curricular considerations but is nomally given direction by an interest structure based on academic careers and the public use of knowledge" (Barnett, 1992:623). Hy argumenteer dat die "logika" van navorsing ingrypend verskil van dié van onderrig Indien die belang van navorsing vir hoër onderwys te veel beklemtoon word, lei dit noodwendig daartoe dat onderig "a back seat" inneem, tot nadeel van die gehalte en doeltreffendheid van die hoür-onderwyssisteem 


\section{Eenheid van navorsing en onderrig?}

Ek dink dat 'n mens versigtig moet wees dat die pendulum nie in beskouings oor die verhouding tussen navorsing en onderrig binne universitêre verband van die een uiterste na die ander deurswaai nie. Aan die een kant is dit waar dat die doseertaak aan universiteite nie só ten gunste van navorsing verwaarloos mag word dat die primêre onderwysfunksie en pedagogiese doelstellings van die universiteit uiteindelik daaronder ly nie. Dit kan egter aan die ander kant net so maklik gebeur dat ' $n$ oorheersende aksent op die belang van onderrig ' $n$ rookskerm word waaragter 'n gebrek aan navorsingsgeesdrif en navorsingsaktiwiteit verberg word. Die ongekwalifiseerde pleidooi vir onderrig, in opposisie tot navorsing, kan ook lei tot ' $n$ verenging van die navorsingsbegrip, met verontagsaming van daardie navorsingskomponente wat juis die rugsteun is van goeie onderrig. Die verbintenis tot universitêre onderrig en die verbintenis tot universitêre navorsing sluit mekaar nie onderling uit nie. Die probleem, soos ek vroeër opgemerk het, is egter hoe om in sowel teorie as praktyk die regte balans tussen hierdie twee funksies van die universiteit te vind.

'n Oënskynlik ewewigtiger siening oor die verhouding tussen onderrig en ondersoek in 'n universitêre konteks word verteenwoordig deur teoretici en filosowe soos Karl Jaspers (Jaspers, 1946) wat tot 'n groot mate die basiese beskouinge van die 19de-eeuse denker Wilhelm von Humboldt oor die idee van die universiteit hervertolk het. In hierdie omgewing word onderrig en ondersoek nie teenoor mekaar afgespeel of aan mekaar ondergeskik gemaak nie. Die uitgangspunt is hier juis die eenheid van onderrig en ondersoek as twee funksies van die universiteit wat nie los en onafhanklik van mekaar bestaan nie, maar intrinsiek na mekaar verwys as twee kante van dieselfde munt. Onderrig en ondersoek is nie in ' $n$ zerosom-spel gemoeid nie, maar eerder in 'n verhouding van onderlinge ondersteuning en verryking. 5

Volgens hierdie beskouing is die verwerwing, bewaring en mededeling van kennis komplementêre aspekte van die een strewe na kennis waaraan die universiteit sy ontstaan en bestaan te danke het. Vanselfsprekend is dit moontlik dat die verskillende aspekte van die strewe na kennis vir praktiese redes apart georganiseer en selfs deur onderskeie soorte instellinge behartig kan word. Wesenlik hoort hulle egter by-

5 Volgens Von Humboldt, die dryfkrag agter die stigting van die Universiteit van Berlyn in 1810 , is die "eenheid tussen onderrig en navorsing" een van die vier basiese komponente in die "idee van die universiteit." Vergelyk hieroor onder meer Rohrs (1995); Bertilsson (1992); Shils (1992) 
Die verhouding tussen ondering en navorsing in universitêre verband

mekaar. En die universiteit is juis daardie besondere instelling waarin die genoemde funksies in hulle eenheid, dit wil sê in hulle onderlinge samehang en interafhanklikheid, gestalte gevind het. Die eenheid tussen onderrig en navorsing is daarom ook een van die onderskeidende hoedanighede van die universiteit as universiteit. Indien onderrig en navorsing van mekaar geskei word, sê Jaspers, sterf die gees van die universiteit en kom die spesifiek universitêre karakter van onderrig en navorsing self tot ' $n$ einde.

Hierdie teoretiese beklemtoning van die eenheid van onderrig en ondersoek klop met ' $n$ intuitiewe besef wat by baie akademici leef. Daar is 'n soort konvensionele wysheid dat hierdie universitêre funksies by mekaar hoort en dat die een sonder die ander noodwendig sal ly (vgl. Neumann, 1992). Die gevoel is dat meer en beter navorsing die omvang en gehalte van onderrig ten goede behoort te kom, en omgekeerd. Een van die uitsprake wat dikwels in die retorika van universiteitsleiers voorkom, is daarom ook dat navorsing en onderrig mekaar in universitêre verband nodig het.

Wat egter nie altyd sonder meer duidelik is nie, is waarom navorsing en onderrig mekaar in universitêre verband nodig het, en in watter opsig. Die vraag is met ander woorde wat die gepostuleerde eenheid van navorsing en onderrig presies beteken, en veral hoe dit in die praktyk tot openbaring kom en dáár 'n verskil maak. Ek dink 'n mens kan hierdie vraag op twee maniere probeer beantwoord. Die eerste hiervan is om die gepostuleerde eenheid te probeer verstaan as 'n beskrywende begrip wat die bedoeling het om te sê wat die geval in die praktyk feitelik is. Die tweede manier om die gepostuleerde eenheid te verstaan is om dit as 'n normatiewe begrip te benader wat aandui wat die geval in die praktyk idealiter gesproke - behoort te wees. Geinterpreteer as 'n beskrywende begrip is die veronderstelling dat dit na 'n aktuele stand van sake verwys. Geinterpreteer as 'n normatiewe begrip is die veronderstelling dat dit die uitdrukking is van 'n rigtinggewende strewe.

'n Mens kan die gepostuleerde eenheid of unie tussen onderrig en navorsing as ' $n$ beskrywende begrip verstaan deur 'n empiriese inhoud daaraan te probeer gee. Daar kan geargumenteer word dat indien onderrig en ondersoek binne universitêre verband op ' $n$ interafhanklike wyse met mekaar saamhang, daar ook in die praktyk waarneembare, feitelike korrelasies tussen die twee moet wees wat empiries getoets sou kan word. Die moontlike positiewe bevinding van sulke toetse sal 'n aanduiding gee van die beskrywende elemente wat in die begrip vervat is. Daar is dan ook inderdaad allerlei empiriese studies onderneem met die oog op die vasstelling van sulke waarneembare korrelasies tussen onderrig en navorsing. 
Die manier waarop te werk gegaan word, is om by wyse van afleiding verwagtings wat deur die gepostuleerde eenheid geimpliseer word, uit te spel en te kyk tot watter mate hierdie verwagtings in die praktyk gerealiseer word al dan nie. So is die hipotese byvoorbeeld empiries getoets dat daar 'n korrelasie sal wees tussen die navorsingsproduktiwiteit en die onderrigeffektiwiteit van individuele akademici. Die vraag is hier of die navorser wat met die hoeveelheid en hoedanigheid van sy of haar uitsette presteer, in die reel ook 'n dosent is wat met onderrig opsigtelike sukses behaal. 'n Ander kwessie wat ondersoek is, is tot watter mate die prosedures en skemas wat ondersoekers volg by die aanpak en uitvoering van hulle navorsing, ook in die praktyk as ' $n$ soort model dien vir die beplanning en organisasie van die onderrigsituasie. Nog 'n studie het gegaan oor die moontlikheid dat die onderrig van 'n akademikus ' $n$ belangrike bron vir nuwe navorsingsidees en navorsingsinisiatiewe kan wees. Verskillende ondersoeke is tewens onderneem om die psigologiese korrelasie vas te stel tussen die persoonlikheidseienskappe wat met navorsingsprestasie geassosieer is, en dié wat gewoonlik by suksesvolle dosente voorkom.

In al die studies waarvan ek bewus is, het die empiriese getuienismateriaal egter tot uiteenlopende bevindings gelei, sommige negatief, ander neutraal, nog ander matig positief of gewoon moeilik interpreteerbaar. In geeneen van die opsigte wat ondersoek is, was daar ondubbelsinnige empiriese bevestiging van 'n sterk positiewe korrelasie tussen onderrig en navorsing nie. Probeer 'n mens sin maak van die gesamentlike resultate van dergelike empiriese studies, stuit jy origens op allerlei faktore wat 'n koherente konklusie bykans onmoontlik maak. Die belangrikste hiervan is miskien die feit dat daar nie altyd eenduidige definisies van navorsing en onderrig, en veral nie eenduidige kriteria vir goeie navorsing en goeie onderrig onderskeidelik, gebruik word nie. Dit lyk dus wel asof empiriese gegewens omtrent moontlike korrelasies in die praktyk nie veel lig kan werp op die intrinsieke eenheid tussen ondersoek en onderrig wat teoreties gepostuleer word nie. 6

\section{Die akademiese leerproses}

Persoonlik is ek van mening dat die resultate van empiriese ondersoeke 'n mens wel versigtig moet stem om nie alte maklik feitelike bewerings te maak oor die onlosmaaklike band en interafhanklikheid tussen navorsing en onderrig nie. Terselfdertyd is dit belangrik om daarop te let dat die betrokke ondersoeke meestal alleen in terme van meetbare en telbare word: Webster (1985); Feldman (1987); Shore et al. (1990); Brew en Boud (1995). 
Die verhouding tussen onderrig en navorsing in universitêre verband

resultate, dit wil sê van kwantifiseerbare produkte, gedoen is, en daarby ook alleen met betrekking tot die navorsing en onderrig van die individuele akademikus en nie van 'n akademiese departement of van 'n instelling in sy geheel nie. In elke geval ag ek my nie bevoeg om die aanvaarbaarheid van die gemelde empiriese studies en die houdbaarheid van hulle bevindinge te beoordeel nie. Ek wil daarenteen eerder die tweede weg beproef en kyk hoever dit ' $n$ mens kan bring. Dit beteken dat ek die gepostuleerde eenheid tussen onderrig en navorsing wil verstaan as ' $n$ normatiewe begrip wat nie 'n empiries toetsbare beskrywing probeer gee van wat is nie, maar eerder ideale impliseer van wat behoort te wees. Volgens hierdie benadering verwys die gepostuleerde eenheid dus nie noodwendig na 'n feitelike stand van sake in die praktyk nie, maar vertolk dit eerder 'n strewe waaruit riglyne vir praktiese beleidsdoelstellings en -prioriteite afgelei kan word. Ek meen dat dit hierdie benadering is wat ten grondslag lê aan die beskouinge van teoretici soos Von Humboldt en Jaspers.

Die eenheid wat Von Humboldt en sy medestanders op die oog gehad het as ' $n$ onderskeidende hoedanigheid van die ideale universiteit, berus op die uitgangspunt dat universitêre ondersoek en onderrig struktureel op mekaar aangewys is in ' $n$ verhouding van simbiose. Wat daarmee bedoel word, is dat universitêre onderrig nie sonder universitêre ondersoek kan bestaan nie. Dit is juis universitêre onderrig danksy sy simbiotiese verhouding met universitêre ondersoek. Omgekeerd kan universitêre ondersoek nie sonder universitêre onderrig bestaan nie. Dit is juis universitêre ondersoek deur die simbiotiese verhouding waarin dit tot universitêre onderrig staan. En dit is mede in en deur die strewe na so 'n simbiotiese verhouding dat die universiteit in beginsel ' $n$ eiesoortige institusionele dinamika en kultuur kan ontwikkel.

Dit is ongetwyfeld so dat daar instellings kan wees waar slegs onderrig gegee word, dit wil sê waar kennis oorgedra, waardes aangekweek of in vaardighede opgelei word, sonder dat iets gedoen word aan die verwerwing van nuwe kennis en insig. Sulke instellings hou hulle egter nie noodwendig met universitêre onderrig besig nie, selfs al sou hulle ook universiteite genoem word. Net so kan daar instellings of organisasies wees waar net ondersoek gedoen word, dit wil sê waar net op die ontdekking van nuwe kennis of die kognitiewe oplossing van praktiese probleme gekonsentreer word. Sulke liggame hou hulle egter eweneens nie noodwendig met universitêre ondersoek besig nie, selfs al sou hulle ook universiteite genoem word. Van universitêre onderrig en navorsing is daar in beginsel pas sprake wanneer hulle in 'n onderlinge verhouding van simbiose beoefen word. 
Die vraag is hoe 'n mens die aard van hierdie eenheid of simbiotiese verhouding verstaanbaar kan maak. Vir 'n normatiewe begrip van die gepostuleerde eenheid tussen onderrig en navorsing lyk dit my nie baie vrugbaar om uit te gaan van die meetbare of kwantifiseerbare aspekte van die produkte van hierdie kennisoperasies nie. 'n Mens kom veel verder deur daarenteen aan te sluit by die prosesse van onderrig en navorsing onderskeidelik, en te vra watter hoedanighede van hierdie prosesse die twee betrokke kennisoperasies aan mekaar verbind.

Hoewel universitêre ondersoek en onderrig twee verskillende aktiwiteite is wat verskillende vaardighede en geriewe vereis, en ook tot verskillende soorte resultate lei, het hulle as operasies met en ter wille van kennis één ding gemeen. Albei het deel aan, of betrekking op, die besondere leerproses wat deur die akademiese wil tot kennis gekonstitueer word, en wat medebepalend is vir die soortlike identiteit van die universiteit. 7 Die leerproses waarom dit hier gaan, is idealiter gesproke nie bloot 'n klakkelose assimilasie of passiewe absorpsie van inligting of vaardighede wat in die vorm van afgeronde produkte as 't ware meganies oorgedra word of vir ontdekking beskikbaar is nie. As akademiese leerproses is dit inteendeel 'n leerproses wat enersyds gekenmerk word deur 'n aktiewe, kreatiewe, en toenemend selfgereguleerde deelname aan die opbou van betekenis en die verwerwing van insig. Andersyds is dit 'n leerproses wat in die woorde van Wyatt (1990) gekarakteriseer word deur "an openness to continuous enquiry", 'n onafsluitbare kritiese vraagstelling waarin verworwe insigte getransendeer en deurlopend gesoek word na alternatiewe moontlikhede van kennis en begrip. Dit is hierdie leerproses wat aan universitêre onderrig en ondersoek struktureel hulle onderlinge samehang en daarmee ook hulle eiesoortige universitêre aard gee. Ek kan ook sê dat die akademiese leerproses die hart van die universiteit is wat die universitêre lewensbloed na sowel die universitêre onderrig as die universitêre navorsing pomp

Indien 'n mens die eenheid tussen onderrig en ondersoek normatief in terme van die akademiese leerproses probeer verstaan, sal dit vanselfsprekend konsekwensies hê vir die wyse waarop die belang en die aard van hierdie twee funksies self afsonderlik gekonsipieer word. Navorsing en onderrig is hiervolgens alleen dan van universitêre gestalte en gehalte wanneer dit die akademiese leerproses beliggaam, respektiewelik

7 Ek sluit vir hierdie beklemtoning van die akademiese leerproses as eenheidskonstituerende faktor in die verhouding tussen onderrig en ondersoek aan by gedagtes van Brew en Boud (1995); Fincher (1993;) Wyatt (1990) en Shore et al. (1990). 
bevorder. So gesien, beteken universitêre navorsing in die omvattende sin van die woord 'n verbeeldingryke, skeppende leeraktiwiteit waarin nuwe kennis of insig nagestreef word; maar dan 'n leeraktiwiteit wat afspeel binne die raamwerk en in die verlengde van die dissiplinegebaseerde kennistradisies wat deur die akademiese gemeenskap in die onderrigproses bewaar en lewend gehou word. Universitêre navorsing is die reflektiewe en kritiese heropname en ontginning van oorgelewerde kennis, met die oog daarop om dit in nuwe ontdekkings te transendeer Hoewel individue hierby betrokke is, is die subjek van die akademiese leerproses in hierdie geval die akademiese gemeenskap, dit wil sê die gemeenskap van geleerdes wat al lerende deelneem aan 'n wete-inontwikkeling, aan ' $n$ oop en voortgaande proses van sistematiese kennisvernuwing

Universitêre onderrig is aan die ander kant die inisiëring, fasilitering en bestuur van die akademiese leerproses by die lerende individu. Hierdie inisiëring en fasilitering geskied deur die lerende individu in te lei in die kognitiewe tradisies van ' $n$ bepaalde dissipline of dissiplines. ' $n$ Dergelike inleiding beteken egter nie net om die student wat na kennis streef deel te gee aan die bestaande korpus van kennis en insig nie. Dit beteken veral ook om die gees van ondersoekende en oop vraagstelling tuis te bring en te ontwikkel; daardie gees naamlik wat die dryfkrag is agter die immer voortskrydende en onvoltooibare akademiese leerproses soos dit ook in die navorsingsaktiwiteit van die universiteit tot openbaring kom. Die subjek is hier die individuele leerder wat enersyds tot nuwe insig gelei en begelei moet word; andersyds self die nuwe insig deur kreatiewe intellektuele inspanning persoonlik moet verwerf.

Ek herhaal dat hierdie beskouings oor die eenheid van universitêre onderrig en ondersoek nie die status van ' $n$ empiries getoetste of toetsbare beskrywende teorie het nie. Dit is daarenteen ' $n$ voorstel waarin die idee van die universiteit self in terme van normatiewe ideale vertolk word. Of dit ideale is wat kan werk, hang daarvan af of hulle in praktiese en praktiseerbare beleidsrigtings vertaal en so 'n verskil in die sfeer van universitêre handeling kan maak.

In terme van hierdie ideale beteken dit dat die akademiese leerproses, en nie akademiese kennisprodukte nie, in die praktyk die fokus van sowel navorsing as onderrig behoort uit te maak. Want dit is alleen dan dat die simbiotiese eenheid en onderlinge ondersteuning, en daarmee ook die eiesoortige universitêre karakter, van hierdie twee universitêre funksies tot hulle reg kan kom. Dit impliseer dat onderrig aan die een kant afgestem behoort te wees op die inisiëring in en fasilitering van die akademiese leerproses as ' $n$ altyd voortgaande heropname en kritiese transendering van bestaande kennis en insig. Waar dit nie die geval is 
nie, loop onderrig gevaar om niks meer te word nie as die reproduksie van gefikseerde resultate, as die skoolse oordrag van netjies verpakte informasie, tegnieke en vaardighede. Binne 'n suiwer opleidingskonteks mag so 'n oordrag van voltooide produkte met die oog op onkritiese assimilasie waarskynlik voldoende wees. Onderrig wat binne die kader van die universiteit as akademiese leersentrum aangebied word, sal egter idealiter gesproke daarop uit wees om meer as 'n dergelike assimilasie te bewerkstellig. Hierdie "meer" sal veral neerkom op daardie soort intellektuele vorming wat die eksperimenterende gees van kritiese vraagstelling en kreatiewe verbeelding vaardig maak. Dit is met ander woorde daardie soort vorming wat die openheid skep en die impetus verskaf wat nodig is om op ' $n$ voortgesette basis ondersoekend en ontdekkend te leer.

Die verbintenis van die kant van die akademikus tot 'n dergelike onderrigaktiwiteit sal onder meer die gewilligheid impliseer om as dosent self ook in en deur sy of haar onderrig te leer. Die fasilitering van 'n effektiewe akademiese leerproses by die student veronderstel naamlik die deurlopende herdink en herevaluering van onderrigmateriaal en die intellektuele ontwikkeling wat daarmee gepaard gaan. Dit veronderstel met ander woorde dat die dosent self krities-ontdekkend besig sal bly in die onderrig wat gegee word. In hierdie sin is goeie onderrig onderrig wat self deur die akademiese wil tot kennis geinspireer en gedryf word, en wat daarom self die navorsingsgees van reflektiewe skepsis en kreatiewe verbeelding adem.

Die normatiewe "simbiose" tussen onderrig en navorsing binne universitêre verband beteken aan die ander kant dat navorsing sal inskakel by die kognitiewe tradisies en dissiplines van die akademiese leerproses soos hierdie tradisies en dissiplines in die universitêre onderrigaktiwiteit bewaar en oorgelewer word. Indien dit nie gebeur nie, ontwikkel navorsing maklik as 'n geheel en al aparte en op sigself staande onderneming wat deur eksterne belange en behoeftes gedryf word en geen sigbare verband meer het met die onderrigproses en die leerplan nie. Navorsing is dan nog in die universiteit, maar nie meer van die universiteit nie. Dit is dan dat navorsing ook al hoe meer ontwikkel tot die geroetineerde uitvoering van korttermynprojekte of die aflewering van bruikbare produkte. Maar universitêre navorsing is idealiter gesproke iets anders as ' $n$ bedryfsoperasie wat in ' $n$ volslae verbruikersgeoriënteerde benadering pasklaar kennispakkette aan die lopende band produseer. Universitêre navorsing is eerder die deelname, binne die akademiese gemeenskap, aan 'n kollektiewe, sistematiese leerontwikkeling wat as 'n selfoorstygende beweging deur die wil tot kennis gekonstitueer en gedryf word, en in beginsel onvoltooibaar is. Die verbintenis tot navorsing as ' $n$ modus van die akademiese leerproses sal voorkom dat aan akademiese 
kennis alleen gedink word in terme van afgehandelde produkte of gepubliseerde resultate, met verontagsaming van die subjektiewe prosesse van gissing en vergissing, van kritiese refleksie en kreatiewe verbeelding wat ' $n$ rol gespeel het in die ontstaan daarvan (vgl. Brew en Boud, 1995).

\section{Praktiese implikasies}

Wanneer daar in die bo omskrewe sin van die woord sprake is van 'n eenheid tussen navorsing en onderrig, is die vraag natuurlik wat hierdie eenheid of simbiose nog verder in praktiese terme alles impliseer vir die organisasie, operasionalisering en uitvoering van die universiteit se basiese funksies. Ek dink daar is sekere dinge wat dit nie impliseer nie en wat ek graag eerste wil noem.

Die eenheid tussen onderrig en navorsing impliseer nie noodwendig 'n gelyke verdeling van die tyd, fondse of mensekrag wat aan die twee onderskeie universiteitstake bestee word nie. In die akademiese leerproses is dit kwaliteitskriteria en kwaliteitsbehoeftes wat die deurslag gee en nie 'n kwessie van hoeveelhede nie. Dit gaan, of behoort te gaan, om die vraag hoe bronne die beste aangewend kan word om gehalte te verseker, eerder as om die vraag of die beskikbare bronne gelykop tussen take verdeel is.

Die eenheid tussen navorsing en onderrig beteken ook nie dat meer en intensiewer navorsing in 'n bepaalde dissipline noodwendig deur 'n toename in onderrigaktiwiteite geëwenaar moet word, of omgekeerd nie. Verskuiwings in hierdie verband word normaalweg op 'n natuurlike wyse gereguleer deur die dinamika van dissiplinêre ontwikkeling enersyds en van die interaksie met samelewingsbehoeftes andersyds. Eweneens beteken dit nie dat elke individuele akademikus tot dieselfde mate in albei funksies aktief moet wees nie. Die eenheid van onderrig en ondersoek in die leerproses is 'n eenheid wat in die werksaamhede van die akademiese gemeenskap weerspieël behoort te word, en nie noodwendig in die werksaamhede van elke individuele akademikus nie. Die eenheid laat 'n rolverdeling binne die breë akademiese gemeenskap toe in ooreenstemming met individuele aanleg en belangstelling.

Wat die eenheid egter wel beteken, is eerstens dat onderrigverantwoordelikhede en navorsingsinisiatiewe onderskeidelik nie die basis sal word vir die vorming van aparte groepe wat hulleself tot verskillende kategorieë reken en ook as sodanig deur die instelling gehanteer en geëtiketteer word nie. 'n Dergelike benadering dra by tot spanning, verwydering en argwaan, en uiteindelik tot die disintegrasie van die akademiese gemeenskap. Om sulke afgeslote kompartemente te vermy, 
en die fragmentering wat daarmee gepaard gaan, is nie net ' $n$ institusionele etos en kultuur van samehorigheid en solidariteit nodig nie. Wat nodig is, is ook die daadwerklike beplanning van kommunikasiegeleenthede sodat die gees en die dinamika van die akademiese leerproses ("the openness for continous enquiry") die instelling in sy geheel kan deursuur en sowel die onderrig as die ondersoek kan beheers. Elke akademikus sal in sy of haar hoedanigheid as dosent die verantwoordelikheid hê om hom- of haarself met begrip op hoogte te stel van die sleutelkwessies wat in navorsingsdebatte aan die orde is. Elke akademikus sal in sy of haar hoedanigheid as navorser ingelyks die verpligting hê om vertroud te raak en te bly met die aktuele behoeftes, eise en aksente van die veranderende onderrigsituasie. ' $n$ Mens kan dit ook anders stel deur te sê dat elke akademikus sorg moet dra dat sy of haar dissiplinêre loopbaan - waarin navorsing gewoonlik die toon aangee, en waarin die neiging daarom ook is na die assosiasie met vakgenote op nasionale en internasionale vlak - nie digotomies weggroei van sy of haar institusionele loopbaan nie - dit wil sê van daardie loopbaanmodaliteit waarin veral onderrig domineer, en waarin verpligtinge en betrekkinge hoofsaaklik beperk is tot die instelling self.

In aansluiting by die voorafgaande sou tweedens ook verwys kan word na ' $n$ aspek van kollegiale kommunikasie wat van besondere belang kan wees in die vernuwing van onderrig. Uitwisseling van idees en onderlinge beoordeling van prosedures en resultate deur eweknieë is een van die wesenlike kenmerke van gehalteversekering in die navorsingsproses. Die vraag is of daar nie ook dergelike gebruike en strukture ten opsigte van onderrig ontwikkel kan word nie. Dikwels is die dosent vir die kritiese evaluering en vernuwing van eie onderrig geheel en al op hom- of haarself aangewys. Van die akademiese gemeenskap wat by die akademiese leerproses betrokke is, is daar in so ' $n$ geval weinig sprake. Kan die onderrigaktiwiteit van die dosent nie self aanmerklik aangehelp en gestimuleer word deur geleenthede te skep waar spesifieke onderrigpogings, of aspekte van onderrig soos handboekkeuses en klasaantekeninge, in kollegiale verband bespreek, beoordeel en hersien kan word nie? Net soos in die geval van navorsing is daar ook wat onderrig betref, plek vir 'n kollegiale netwerk van samewerking en onderlinge kritiek (vgl. Elrick et al., 1996). 'n Gesamentlike noukeurige ondersoek van onderrig kan help verseker dat onderrigstrategieë meer afgestem word op die fasilitering van die akademiese leerproses, en dat nie net kennisprodukte vir studente aangebied word om te assimileer nie, maar dat studente veral blootgestel word aan die kreatiewe ondersoekstappe van die proses waarin kennis en insig tot stand kom.

Indien die eenheid tussen navorsing en onderrig, soos dit deur die akademiese leerproses tot stand kom, tot die onderskeidende hoedanig- 
hede van die universiteit behoort, beteken dit derdens ook dat daar nie sprake kan wees van 'n onderskeiding en skeiding tussen "onderriguniversiteite" en "navorsingsuniversiteite" nie. Daar kan wel in die normale gang van sake 'n hiërargie of rangorde van beter en minder goeie universiteite ontwikkel. Elke instelling wat egter aanspraak wil maak op die benaming "universiteit", sal 'n toepaslike ewewig moet soek en vind tussen onderrig en navorsing.

Die eenheid kan vierdens beteken dat die leerplan en die navorsingsprogramme en -temas in 'n bepaalde dissipline sover moontlik verband met mekaar sal hou, ook al val die inhoude nie in alle opsigte saam nie. Dit is 'n manier om te verseker dat navorsing en onderrig die soort toepaslike ewewig behou waarna ek so pas verwys het. Sonder enige tematiese verband loop onderrig en navorsing gevaar om elk sy eie weg op te gaan. Dit is dan dat die produkbenadering ook begin oorheers en die vraag nie meer is hoe die akademiese leerproses bevorder en vernuwe kan word nie, maar eerder in watter eksterne behoeftes daar met kennisresultate of kennispakkette voorsien kan word. Indien daar egter wel so ' $n$ tematiese verband is, is die kanse groter dat die leeraktiwiteit van die student wat deur die onderrigproses gefasiliteer word, ook 'n kennismaking op inhoudelike vlak sal behels met die leeraktiwiteit soos dit in die navorsingsproses afspeel. Die student sal met ander woorde as 't ware eerstehands vertroud gemaak word met en begrip opdoen van die kreatiewe denke wat by die vorming van nuwe insigte en die ontdekking van nuwe kennis betrokke is. Sy leeraktiwiteit sal sodoende nie die drink van 'n stilstaande poel wees nie, maar van 'n lopende stroom; nie slegs die ontvangs van ' $n$ afgeplukte blom nie, maar 'n kennismaking met die versorging van die groeiende plant.

Ek volstaan met hierdie enkele suggesties. ' $n$ Mens kan verwag dat daar steeds verskil van mening sal wees oor die relatiewe belang van die onderrig- en ondersoektake van die universiteit onderskeidelik. Ek glo egter dat vrugbare perspektiewe op die oënskynlike spanning tussen hierdie twee take ontwikkel kan word deur uit te gaan van die akademiese leerproses as die samebindende faktor. So 'n uitgangspunt kan terselfdertyd help om ' $n$ duideliker beeld te kry van die simbiotiese verhouding tussen navorsing en onderrig as een van die definiërende hoedanighede wat die soortlike identiteit van die universitêre instelling bepaal.

\section{Bibliografie}

ATKINSON, Richard C. \& TUZIN, Donald. 1992. Equilibrium in the research University. Change, 24(3):20-31.

BAKER, P. 1986. The helter-skelter relationship between teaching and research: $A$ cluster of problems and small wins. Teaching Sociology, 14(1):50-66. 
BARNETT, Ronald. 1992. Linking teaching and research. A critical inquiry. Journal of Higher Education, 63(6):619-636.

BARZUN, Jacques 1991. Begin here The forgotten conditions of teaching and learning. Chicago : University of Chicago Press.

BERTILSSON, Margareta. 1992. From university to comprehensive higher education On the widening gap between 'Lehre und Leben'. Higher Education, 24(3):333349.

BOYER, E.L. 1990. Scholarship reconsidered. Priorities of the professoriate Princeton : Carnegie Endowment for the Advancement of Teaching

BREW, Angela \& BOUD, David. 1995. Teaching and research: Establishing the vital link with learning. Higher Education, 29(3):261-273

DALY, William T. 1994. Teaching and scholarship. Journal of Higher Education, 65(1):45-57

ELRICK, R.M., JENKINSON, G.M. \& THOMAS, R.L. 1996. Academic collegiality in research and teaching. Journal of Nature Resources in Life Science Education. 25(1):71-74.

ELTON, Lewis. 1986. Research and teaching: symbiosis or conflict? Higher Education, 15(3):299-304.

FELDMAN, K.A. 1987. Research productivity and scholarly accomplishment of college teachers related to their instructional effectiveness: A review and exploration. Research in Higher Education, 26(3):272-298.

FINCHER, Cameron. 1993. The Idea of the UNIVERSITY in the 21st century: An American perspective. British Journal of Educational Studies, 41(1):26-45

JASPERS Karl. 1946. Die Idee der Universität. Berlin : Springer.

NEUMANN, R. 1992. Perceptions of the teaching-research nexus: A framework for analysis Higher Education, 23(2):159-172.

NEWMAN, John. 1910 [1852]. The idea of a university. London : Longman, Green.

NISBET, Robert 1971. The degradation of the academic dogma. London Heinemann.

OECD. 1987. Universities under scrutiny. (Report written by William Taylor.) Paris : Organisation for Economic Co-operation and Development.

PAULSEN, Michael B. \& FELDMAN, Kenneth A. 1995. Toward a reconceptualization of scholarship. Journal of Higher Education, 66(6):615-640.

RÖHRS, Hermann. 1995. The classical German concept of the university and its influence on higher education in the United States. Frankfurt am Main : Peter Lang.

SHILS, Edward 1992. The idea of the university: Obslacles and opportunities in contemporary society. Minerva, 30(2):301-313.

SHORE, Bruce M., PINKER, Susan \& BATES, Mary. 1990. Research as a model for university teaching. Higher Education, 19(1):21-35

TOCH, Thomas. 1990 A return to teaching? U.S. News and World Report, 109(15) 107-109.

WEBSTER, D.S. 1985. Does research productivity enhance teaching? Educational Record, 66(4):60-62.

WYATT, John. 1990. Commitment to higher education. Buckingham : Open University Press. 
Die verhouding tussen onderrig en navorsing in universitêre verband

\section{Kernbegrippe:}

akademie

humaniora

navorsing

onderrig en navorsing, die verhouding

universiteit, kerntake

\section{Key concepts:}

academia

humaniora

research

teaching and research, the relation

university, core tasks 